\section{Effects of intraperitoneal injection of ethanol on ethanol ingestion of C57BL mice ${ }^{1}$}

GERALD E. MCCLEARN, Institute for Behavioral Genetics, University of Colorado, Boulder, Colo. 80302, and DA VID NICHOLS, University of Colorado, Colorado Springs, Colo. 80907

When intraperitoneal injections of an ethanol solution are given to CS7BL mice (an alcohol-preferring strain), their free-choice ingestion of ethanol during the next $24 \mathrm{~h}$ is reduced by an amount approximating the injected amount. The ethanol-intake control system of these mice is evidently not dependent upon taste or other stimuli associated with ingestion.

Several studies (e.g., McClearn \& Rodgers, 1959, 1961) have shown that various substrains of C57BL mice display a preference for $10 \%$ ethanol in a two-bottle choice situation. Although the precise values vary from experiment to experiment, the general finding is that these animals consume more than $50 \%$ of their total liquid intake from the ethanol source, thus demonstrating that the consumption is not due to indifference or inability to detect the ethanol in solution. Equally interesting is the fact that the animals do not drink exclusively from the ethanol source. These observations imply the existence of a regulatory system that, in some fashion, sets bounds on the amount of ethanol ingested. This ethanol-intake control system, abbreviated EICS for convenience, may be very complex, involving peripheral sensory and central neural factors and various metabolic processes. Description of the EICS should prove to be useful not only in respect to alcohol research, but also for the study of motivational processes in general. Previous research (McClearn, 1968) has shown that C57BL animais, when offered a choice between water and an ethanol 1 p.m. daily. Injection, refilling of bottles,

Table 1

\begin{tabular}{|c|c|c|c|c|c|c|c|c|c|c|}
\hline \multirow[b]{3}{*}{ Day } & & & \multicolumn{4}{|c|}{ Change in Intake } & \multirow{2}{*}{\multicolumn{2}{|c|}{$\begin{array}{c}\text { Total Liquid } \\
\text { Consumption } \\
\text { (Postinjection Day) }\end{array}$}} & \multirow{2}{*}{\multicolumn{2}{|c|}{$\begin{array}{c}\text { Body } \\
\text { Weight }\end{array}$}} \\
\hline & & & \multicolumn{2}{|c|}{ Ethanol } & \multicolumn{2}{|c|}{ Water } & & & & \\
\hline & \multicolumn{2}{|c|}{ Condition } & $\mathrm{T}$ & $\mathrm{C}$ & $\mathrm{T}$ & $\mathrm{C}$ & $\mathrm{T}$ & $\mathrm{C}$ & $\mathbf{T}$ & $\mathrm{C}$ \\
\hline 15 & INJ & PC & -1.6 & -0.7 & 1.0 & -0.3 & 4.6 & 5.2 & 24.1 & 24.3 \\
\hline 18 & INJ & PC & -1.3 & -0.2 & 0.9 & -0.5 & 4.8 & 4.9 & 24.3 & 24.7 \\
\hline 21 & INJ & PC & -1.7 & -0.7 & 1.4 & 0.5 & 5.1 & 5.2 & 24.2 & 24.9 \\
\hline 24 & INJ & $\mathrm{PC}$ & -0.6 & -0.4 & 0.5 & 0.0 & 4.4 & 4.7 & 24.4 & 25.2 \\
\hline 27 & & PC & 0.0 & -0.1 & 0.1 & 0.0 & 5.2 & 5.0 & & \\
\hline 30 & & PC & -0.1 & -0.3 & 0.0 & 0.0 & 5.0 & 4.8 & & \\
\hline 33 & INJ & PC & -1.1 & -0.7 & 0.8 & 0.2 & 4.7 & 4.7 & 24.3 & 25.6 \\
\hline 36 & INJ & & -1.1 & -0.4 & 0.9 & 0.2 & 4.6 & 4.8 & 24.2 & 25.4 \\
\hline
\end{tabular}

$I N J=$ injection $; P C=$ position change; $T=$ treatment group; $C=$ control group and position changes were made promptly thereafter.

\section{RESULTS AND DISCUSSION}

The principal data are the differences in ethanol-solution intake between the 24-h period preceding the injections and the 24-h period following the injections. These values are shown in Table 1 . The control injections had an effect of lowering ethanol consumption slightly, but the ethanol injections had a larger effect.

The possibility that treatment animals were simply made ill by the injection, with their debility resulting in lowered ethanol ingestion, can be assessed in part. Ill animals might be expected to lose body weight or to reduce water consumption as well as ethanol consumption on the days following injections. Table 1 provides the relevant data. Total liquid consumption on postinjection days did not differ between the groups. Body weights were taken on all injection days. There is a tendency for treatment animals to weigh less than control animals, but this difference amounts to less than $5 \%$ by the end of the experiment, and this seems insufficient to indicate serious illness.

Over all six injection occasions, the mean reduction in the treatment group was $1.2 \mathrm{ml}$, and that for control animals was 0.5 . The difference between the groups is significant $(p<.002)$. The difference of $0.7 \mathrm{ml}$ of $10 \%$ solution is similar in respect to total amount of ethanol to the amount of injected ethanol $(0.5 \mathrm{ml}$ of $20 \%$ solution). Early in the experiment, on the first three injection occasions, the excess reduction of ethanol ingestion by the treatment group over the control group almost exactly equalled the amount injected.

The lack of an ethanol-intake drop in both groups on Days 27 and 30 shows that the position change alone was not influential. The difference between groups on Day 36 shows that the injection need not coincide with a position change in order to be effective.

The results suggest that the EICS responds to absolute amounts of ethanol in the system. Although taste and other stimuli associated with drinking may be involved in the regulation of ethanol intake of normal, untreated animals, it is clear that they are not essential. When ethanol is administered by a route that bypasses these stimuli, it is detected and normal ingestion is reduced by an approximately equivalent amount.

\section{REFERENCES}

MCCLEARN, G. E. Genetics and motivation of the mouse. In W. J. Arnold (Ed.), Nebraska symposium on motivation, 1968. Lincoln: University of Nebraska Press, 1968. Pp. 47-83. 
MCCLEARN, G. E., \& RODGERS, D. A. Differences in alcohol preference among inbred strains of mice. Quarterly Journal of Studies on Alcohol, 1959, 20, 691-695.

McCLEARN, G. E., \& RODGERS, D. A. Genetic factors in alcohol preference of laboratory mice. Journal of Comparative \& Physiological Psychology, 1961, 54, 116-119.

\section{NOTES}

1. This research was conducted at the University of California, Berkeley, with the support of National Science Foundation Grant G-14221.

2. The Crgl designation identifies the substrain as the one maintained by the Cancer Research Genetics Laboratory, University of California, Berkeley.

\title{
The effect of rearing condition on dominance and emotionality in rats
}

\author{
KERMIT T. HOYENGA and RAYMOND K. LEKAN \\ Western Illinois University, Macomb, Ill. 61455
}

Group-raised Ss were compared to socially isolated Ss on measures of dominance (weight gain during food competition) and emotionality (open-field test). Group-reared Ss were less emotional than isolated Ss. Although the group-reared Ss were dominant on the early trials, difference between groups faded over the 12 days of testing.

The effect of rearing conditions on dominance has produced conflicting data in the literature. Rosen \& Hart (1963) reported that one socially reared subspecies of deer rnice, "bairdii," dominated isolate-reared deer mice of the same subspecies. Uyeno \& White (1967) found, on the contrary, that isolate-reared male Wistar rats dominated their socially reared littermates under "survival motivation" conditions. The following experiment was designed to assess the effect of rearing conditions on male Sprague-Dawley rats.

\section{METHOD}

Twenty-four 45-day-old Sprague-Dawley rats were randomly divided into one group of 12 individually caged Ss and one group of 12 group-caged Ss (four Ss per cage). All Ss were maintained on ad lib food and water. At 93 days of age, all Ss were tested in a $4 \times 4 \mathrm{ft}$ open field. Four photo cells positioned to divide the field into nine equal squares monitored S's activity during a 5-min testing session. At 94 days of age, all Ss were placed on a $23.5-\mathrm{h}$ food deprivation schedule. Ten days later a practice trial was given to each rat to familiarize him with food placement and cage. Test trials began the next day; the procedure and apparatus was the same as that employed by Hoyenga \& Rowe (1969). Each socially reared S was paired once with each isolate-reared $S$.
Competitions were carried out over 12 successive days, one 2-min test session per day. Pairs of Ss competed in different random orders from one testing day to the next. The mean weights of the 12 isolateand group-reared Ss were $333.0 \mathrm{~g}$ and $339.5 \mathrm{~g}$, respectively. All Ss were fed for $1 / 2 \mathrm{~h}$ after the test session.

\section{RESULTS}

A $t$ test showed that isolate-reared $\mathrm{Ss}$ were significantly less active in the open field than were socially reared $\mathrm{Ss}(\mathrm{t}=3.37$, $\mathrm{df}=2, \mathrm{p}<.01)$. An analysis of variance showed no significant difference between groups for dominance. Ss in both groups became more effective competitors across days, producing a significant increase in weight gained during competition with

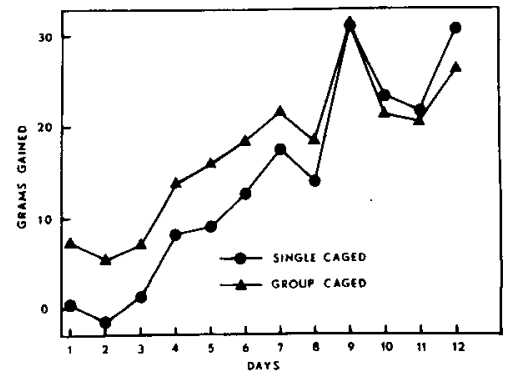

Fig. 1. Weight gain during 12 days of competition. practice $(F=64.36, \mathrm{df}=5 / 110, \mathrm{p}<.01)$. The socially reared Ss initially tended to dominate their isolate-reared competitors, but by Day 9 the differences had faded. This accounts for the significant Group by Days interaction ( $F=3.38, \mathrm{df}=5 / 110$, $\mathrm{p}<.01)$. Sign tests comparing the win-loss record of each $S$ indicated that two socially reared Ss were consistent winners and none were consistent losers; there were three consistent losers among the isolate-reared Ss and no consistent winners $(p<.05)$. The intercorrelations between four variables (weight gain during competition, change in weight across the 12 competition days, original body weight, and open-field activity) were examined for both isolate and socially reared Ss. For both socially reared and isolate-reared $\mathrm{Ss}$, the larger $\mathrm{Ss}$ were more dominant and gained more weight in competition $(r=.41)$. The only other significant correlation indicated that the more active socially reared Ss lost more weight than the less active socially reared Ss over the 12 days of competition $(r=-.61)$.

\section{DISCUSSION}

While some increase in food consumption may be due directly to a decrease in S's fear and task practice, much of the improvement appeared related to the diminished amount of attention paid to the socially reared $\mathrm{S}$ by the isolate-reared S. The isolate-reared Ss during the early trials tended to smell, push, climb over, and in general thoroughly explore the "novel" socially reared S rather than eat. Not only did such behavior reduce the isolate 'Ss' eating, but it also severely disturbed feeding of the socially reared $S$. As the isolate-reared $S$ became familiar with the socially reared $S$, such behavior tended to decline and both became vigorous competitors for the food.

In studies where the same pairs compete over several days (Hoyenga \& Rowe, 1969), Ss tend to consistently win or lose. The present data suggests, however, that when competition is between pairs of Ss unfamiliar with each other, few Ss (5 out of 24) become consistent winners or losers.

\section{REFERENCES}

HOYENGA, K. T., \& ROWE, T. C. Assessing social dominance in pairs of male rats by measuring weight gain. Psychonomic Science, $1969,16,165$.

ROSEN, J., \& HART, F. M. Effects of early social isolation upon adult timidity and dominance in Peromyscus. Psychological Reports, 1963, 13, 47-50.

UYENO, E. T., \& WHITE, M. Social isolation and dominance behavior. Journal of Comparative \& Physiological Psychology, 1967, 63, 157-159. 